\title{
IMPLEMENTATION OF EDUCATION BUSINESS MANAGEMENT IN BANDAR LAMPUNG
}

\author{
Oki Dermawan ${ }^{1}$, Ayu Wulandari ${ }^{2}$, Adri Efferi ${ }^{3}$, Alhamuddin ${ }^{4}$ \\ 1,2Islamic Educational Management Department, Universitas Islam Negeri Raden Intan \\ Lampung, Indonesia \\ ${ }^{3}$ Islamic Educational Management Department, Institut Agama Islam Negeri Kudus, \\ East Java, Indonesia \\ ${ }^{4}$ Islamic Educational Management Department, Universitas Islam Bandung, West Java, \\ Indonesia \\ Email : okidermawan@radenintan.ac.id¹, ayuwulandari.da98@gmail.com², \\ adri.efferi@iainkudus.ac.id ${ }^{3}$, alhamuddinpalembang@gmail.com ${ }^{4}$
}

\begin{tabular}{l|l|l} 
Received: April 2021 & Accepted: July 2021 & Published: August 2021
\end{tabular}

\begin{abstract}
:
The educational institution of Al-Kautsar High School Lampung is an independent institution and carries out several business units. Researchers, in this case, research to find out about the implementation of business management education in Al-Kautsar High School. The type of research used is qualitative. They are collecting data using observation, interviews, and documentation and testing the validity of the data using source triangulation techniques. The results showed that Al-Kautsar High School is an educational institution capable of becoming an independent academic institution. This can be proven by business applications such as canteen, AK water, tutoring, outbound, and umrah. The income from these business units is used to repair, add, and maintain facilities and infrastructure. Private educational institutions have benefited from the implementation of these efforts.
\end{abstract}

Keywords: Business Management, Entrepreneurship, School

\begin{abstract}
Abstrak:
Lembaga pendidikan SMA Al-Kautsar Lampung merupakan lembaga mandiri dan melaksanakan beberapa unit usaha. Peneliti dalam hal ini melakukan penelitian untuk mengetahui tentang implementasi manajemen bisnis pendidikan di SMA AlKautsar. Jenis penelitian yang digunakan adalah kualitatif. Pengumpulan data menggunakan metode observasi, wawancara, dan dokumentasi. Pengujian validitas data menggunakan teknik triangulasi sumber. Hasil penelitian menunjukkan bahwa SMA Al-Kautsar merupakan lembaga pendidikan yang mampu menjadi lembaga pendidikan yang mandiri. Hal ini dapat dibuktikan dengan adanya aplikasi usaha seperti kantin, AK air, bimbingan belajar, outbond, dan umroh. Pendapatan dari unitunit usaha tersebut digunakan untuk memperbaiki, menambah, dan memelihara sarana dan prasarana. Pihak swasta lembaga pendidikan telah merasakan banyak manfaat dengan terselenggaranya usaha tersebut.
\end{abstract}

Kata Kunci: Manajemen Bisnis, Wirausaha, Sekolah 


\section{INTRODUCTION}

Implementation applies ideas, concepts, policies, or innovations in practical action (Kusnandar, 2009). Performance in this discussion uses a thought or statements made by the principal to implement education business management at school (Grover, 2015; Klasik \& Hutt, 2018). Educational business management is a science that studies adequately using the resources in an educational institution as effectively and efficiently as possible to produce material (money) and non-material benefits for academic institutions and make independent schools.

Al-Kautsar Middle School in Bandar Lampung is an educational institution under the Al Kautsar Foundation's auspices and accreditation. The location of this school is on Jl. SoekarnoHatta, Rajabasa, Bandar Lampung. The author chose the title because they saw the importance of implementing business management in education. With the entrepreneur, the principal can make the educational institution an independent institution. Based on the survey results that the author got to serve as empirical data, it is as follows:

Table 1 : Survey Results

\begin{tabular}{cllc}
\hline No. & Business Component. & \multicolumn{1}{c}{ Business Ownership. } & Total \\
\hline 1. & Business Unit Foundation & Canteen & 19 \\
\hline 2. & Business Unit Foundation & Cooperative & 1 \\
\hline 3. & Water Depot (AK Water) & Business Unit Foundation & 1 \\
\hline 4. & High School Foundation & Tutoring & 1 \\
\hline 5. & Business Unit Foundation & Outbound & 1 \\
\hline 6. & Business Unit Foundation & Umrah & 1 \\
\hline
\end{tabular}

Based on the data above, it can strengthen the author's interest in researching at Al-Kautsar High School. This school has run a business of more than two businesses. Other schools rarely do this.

The author cites a theory from Mulyasa (2012) that each school principal must have five essential competencies, namely personality competence, managerial, supervision, social, and entrepreneurship. Of the five critical competencies, entrepreneurial competence is the main issue that has become a national issue recently discussed in education (Tyler, 2016; Mundiri \& Manshur, 2020; Russamsi et al., 2020; Rahman \& Subiyantoro, 2021). How can these educational institutions make graduates who are independent and have personal and entrepreneurial competence so that they are no longer dependent on others, are not unemployed, and do not become a burden on society after graduation (Fatchurrohman, 2018).

Permendiknas No. 13 of 2007 concerning competency standards from the entrepreneurial competency dimension has the following indicators: Creating innovations that are useful for school development. Work hard to achieve school success as an active learning organization. Never give up, always looking for the best solution in facing the obstacles faced by schools. Never give up, always looking for the best solution in meeting the challenges faced by 
schools. Have entrepreneurial instincts in managing school /madrasah production / services as a learning resource for students.

Subiantoro (2017) said that the implementation of the entrepreneurshipbased curriculum has tiered arrangements at each grade level, by the curriculum documents that have been prepared. Each learning process is always integrated with the entrepreneurship aspect, and some have produced products as part of the achievement of student learning outcomes. Margahana (2020) said that entrepreneurship education is very urgent to be enforced at all universities or colleges in all majors or study programs so that students have a high entrepreneurial character. The existence of entrepreneurship education in universities is expected to prepare students to be independent, no longer focused on looking for work but on the contrary to open or create jobs for others.

Dainuri (2019) said that entrepreneurship education is a form of application for the care of the world of education for the nation's progress. Entrepreneurship education shows the values and conditions of work to achieve success. Entrepreneurship education is helping to teach humans so that they have dynamic and creative personal strengths by the personality of the Indonesian nation based on Pancasila. Subroto (2015) said implementation of entrepreneurship education is done by integrating entrepreneurial values in learning.

From several past studies, the difference with this research was that this research was more about implementing entrepreneurship in educational institutions and even had a partnership with outside parties to generate profits for schools. This study aimed to determine how the implementation of education business management in SMA Al Kautsar Bandar Lampung?

\section{RESEARCH METHODS}

The research method is finding and searching for something that previously existed and is still ambiguous. Another term for research methods is achieving goals so that practical activities are logically realized and structured so that the previously expected results can be achieved. The foundation of the research method is a scientific step to obtain data based on specific objectives and functions. The four keywords that need to be considered when carrying out the first research method are the scientific method; the second is the data, the four goals, and the five uses. The meaning of scientific steps in this context is that research activities are based on scientific characteristics, namely logical, empirical, and programmed (Sugiyono, 2017). The form of the study is qualitative, while the state is a direct study. Qualitative research is intended as a step to identify social matters through the perspective of related sources. So the nature of the study is descriptive qualitative, namely separating concepts that connect to the intended discussion in a sequence. His research aims to describe the analysis of the implementation of education business management in SMA Al Kautsar Bandar Lampung.

In qualitative research, the findings or data are declared valid if there is no difference between what the researcher reports and what actually happened to the object under study, and in this study the collected data will be checked 
using transferability techniques, namely the researcher must make a report with a description detailed, clear, systematic so that it can be trusted. Thus the reader becomes clear and decides whether or not the research results can be applied elsewhere. In data collection techniques, triangulation is defined as a data collection technique that combines various data collection techniques and existing data sources. Technique triangulation, meaning that researchers use different data collection techniques to obtain data from the same source. Researchers use observation, interviews, and documentation for the same data source simultaneously. Source triangulation means, to get data from different sources with the same technique.

So in this study, researchers used source triangulation where the data obtained were based on the results of interviews conducted with the head of SMA Al Kautsar Bandar Lampungto find out research questions. Then the data obtained by the researcher categorized which views were the same and which ones were different. Furthermore, the researcher used a triangulation technique where the data obtained from interviews from several sources were then checked with existing documentary data to strengthen. The researcher also went into the field to make observations to get the actual data.

\section{RESULTS AND DISCUSSION}

The author explains from Kompri's book, Principal Competency Standards, that entrepreneurship is a person's behavior to create a helpful innovation and value.

The aim of developing entrepreneurship for school principals is to improve their entrepreneurial quality. The principal can own many dimensions of entrepreneurship; at least a principal must have dimensions of creativity, innovation, hard work, and high motivation and never give up. A school principal can apply an entrepreneurship-based curriculum to create school independence unrelated to government regulations (Kompri, 2017).

This study was carried out at SMA Al Kautsar Bandar Lampung, from December 12 to January 12; it can be seen that the total number of educators is 64 educators, 37 have been certified, and 27 have not. 1,062 students are made up of grades 10-12, including 442 boys and 620 girls. The implementation of educational business management is essential for applying educational institutions to make the institution an independent institution. Therefore, principals must be able to use entrepreneurial skills, one of the latest regulations issued by the Ministry of Education No. 13 of 2007. There are various stages of the implementation process, namely planning, implementation, and control, so that the institutions can operate and continue for a long time. In planning, performance, and management, the ultimate goal is to create an independent educational institution.

Here the author introduces the research results; the research results are as follows: Educational planning to create innovation for school development Business planning is regarded as the planning of entrepreneurs, which embodies the dreams and hopes of encouraging entrepreneurs to start their businesses. In this case, the planning education business is the same as the 
planning company business, and the difference lies only in the organization. In the education business plan, it is also necessary to cover the long-term and short-term coverage of the business to be implemented so that an overview of the benefits to the school can be seen from there. Therefore, an educational business plan is a plan that is planned in the way of running a business in the future, starting with a plan for resource allocation, problem management, and the possibility of seeing business opportunities. Innovation is an idea, element, event, and method. For a person or a group of people, it is a new thing. Whether it is the result of investment or the development of the discovery, it is regarded or observed. In addition, educational innovation is used to solve academic problems.

Therefore, what educational innovation understands is a project, idea, and method that is observed as something new to a person or a group of people, whether in the form of invention or discovery, used to achieve educational goals or solve problems. The results of the research obtained by the researchers from one of the indicators of entrepreneurship of the directors are the following: observe The observation of creating innovative educational business planning for school development is the observation of the enterprise that has been implemented, what is the purpose of the enterprise implementation, who is involved in the enterprise implementation, planning, how the Organizational process is, and how educators help the school principal to instill entrepreneurship in students.

The planning process went well. Unfortunately, SMA Al Kautsar prioritizes students as employees or workers rather than as entrepreneurs. Interview. The interview with the director Eko Anzari, What services does SMA Al Kautsar implement? There are canteens, AK Water, tuition, outbound, and Umrah. What is the purpose of implementing the business? Realize the independence of the foundation-sponsored school and create a sense of comfort for the interior. Who is involved in the business implementation process? What is the foundation itself, the school principal, the faculty, and the staff? The results of the interview with Wen Di, the director of the business department. What business does Al Kautsar High School implement? There are restaurants, overhangs, water tanks (AK Agua), tutorials, Umrah, and cooperatives, but the cooperatives are external; they are not carried out here; they are just rented. Who is involved in the planning process? Participating in the planning process is the builder or foundation of al Kautsar and management, including the principal, teachers, and staff. What is the planning process that can implement the business? From the beginning of the evaluation, Al Kautsar has many students and thousands; of course, they must have the facilities and infrastructure to support their learning process in Al Kautsar. Give an example With the existence of the canteen, after the teaching and learning activities are over, students need to take a break and drink or eat. The water tank (AK Water), part of the business unit, is used for the canteens and large and small units around Al Kautsar. Outbound, internal media is used for students' extracurricular activities, and external media is used for hire by those in need. Umrah is held for exceptional employees who have won the Umrah lottery and 
the community or friends of employees who wish to conduct Umrah. Interview results with educator Angga Wahyu Pratama. How did you help the principal to instill an entrepreneurial spirit in students? Entrepreneurship was introduced at KBM. In these learning activities, the result is that students create products that can be used. In addition, I try to open their minds by comparing what they want to do and their goals in terms of income. For example, if the cost of college is high, graduation may not allow you to find a job, but if the money is used to start a business, if you are good at management, it will increase. Unfortunately, SMA Al Kautsar students focus on becoming workers or day laborers, not entrepreneurs.

The author collects documents in the form of requested businesses, and then the author also gathers documentary evidence from interviews with the interviewees. Apply the company of education to achieve school success as practical learning. The implementation or application in the business world aims to promote our planned business among stakeholders. Promotion is a significant variable in a company's marketing mix when it markets its products and services. In educational institutions, the concept of promotion in question is the marketing carried out by educational institutions to implement established business plans. When determining the promotion strategy, we first divide the promotion according to the combination. The promotion package is divided into five parts: advertising, sales, personnel, direct sales, and public relations. These five marketing updates have the same goal, which is to display and notify products to increase sales. Propaganda should be carried out most attractively to get more public attention. Efforts to promote school development require a lot of thought, cost, and energy and the ability to work for a long time. The director must always work hard. The director must not only depend on hard work or physical strength, but intelligent work is not enough; there is no sincere work and no painstaking work. As an effective learning organization, the principal works hard to make the school successful.

From the author's achievements in implementing educational entrepreneurship as a practical learning study to achieve school success, the following emerges: a. Watch Principals can achieve school success in the business management implementation or implementation process because effective learning is well done. When it comes to researcher observation, the researcher wants to know how the marketing process is carried out and the business application process. Interview with the director Eko Anzari How is the business marketing process carried out? Through the use of media, including electronic printing and other media. Interview with Makmun, Director of Administration As far as you know, how is the director's business in its business execution? All lines are practical and efficient. As far as you know, how does the manager conduct the Marketing process in the process of implementing the company?

Through information media, promotional activities, electronic products, logos, and benefits. Interview with Wen Di, Director of Business Department What is the process of marketing business? Carrying out internal and external promotional activities. This tends to be more internal because the number of 
students, educators, and staff is already significant. Then it is enough for consumers. It is only possible to leave the country, AK water, tutors, and Umrah; it is unnecessary to promote through the media. If possible, it should be expanded.

Entrepreneurship education by educational institutions shows planned and practical efforts to increase knowledge, intentions, and abilities in developing their potential by manifesting creative, innovative, and daring behavior in managing risk (Nurjanah, 2019; Syam et al., 2018). Entrepreneurship is the ability to create new creatively and innovatively to create added value (Hayati et al., 2020)

According to Zulhimma (2018), the fundamental values that must be held important for every entrepreneur are creativity, innovation, risk-taking, responsibility, hard work, and having ethics and morals. An entrepreneur is a person who dares to take risks to open a business in various opportunities (Suryaman \& Karyono, 2018). Having the courage to take risks means being mentally independent and daring to start a business without being overwhelmed by fear or anxiety even in uncertain conditions.

\section{CONCLUSIONS}

Educational business planning to create innovation for school development, the principal has carried out business setting, business goal setting, human resources establishment. With the implementation of this business, it aims to create independent educational institutions and make teachers, educators, staff, and other internal parties within the school's scope prosperous. The implementation of the education business is to achieve school success as practical learning.

The principal has implemented, such as canteens, AK Water, Outbound, cooperatives, tutoring, and Umrah, and the marketing process carried out to maintain the business. The principal has also attempted to instill an entrepreneurial spirit in students through educators. To control the education business, to successfully carry out its primary duties as a leader, the principal has distributed business management or organization, and management run by the foundation, business units, school principals, and staff. Performance evaluation is carried out every month, semester, and annually. The income earned from all business units is to repair and add facilities and infrastructure.

\section{REFERENCES}

Afandi, M. (2021). Implementasi Pendidikan Kewirausahaan (Entrepreneurship) di Sekolah Dasar/Madrasah Ibtidaiyah. Ar-Riayah: Jurnal Pendidikan Dasar, 5(1), 51-64.

Boukamcha. (2015). Impact of Training on Entrepreneurial Intention: an Interactive Cognitive Perspective. European Business Riview, 27(6), 593616. 
Chen, C. C., Greene, P. G., \& Crick, A. (1998). Does Entrepreneurial Self-efficacy Distinguish Entrepreneurs from Managers? Journal of Business Venturing, 13(4), 295-316. https;//doi.org/10.1016/S0883-9026(97)00029-3

Dainuri, D. (2019). Kontribusi Pendidikan Entrepreneurship: Suatu Upaya Konstruktif Menumbuhkan Jiwa Wirausaha pada Mahasiswa. Journal of Sharia Economics, 1(1), 1-13.

Drnovsek, M., Wincent, J., \& Cardon, M. S. (2010). Entrepreneurial Self-efficacy and Business Start-up: Developing a Multi-dimensional Definition. International Journal of Entrepreneurial Behaviour and Research, 16(4), 329348. https:/ / doi.org/10.1108/13552551011054516

Farashahi, M., \& Tajeddin, M. (2018). Effectiveness of Teaching Methods in Business Education: A Comparison Study on the Learning Outcomes of Lectures, Case Studies and Simulations. International Journal of Management Education, 16(1), 131-142. https://doi.org/10.1016.j.ijme.2018.01.003

Fatchurrohman, R. (2018). Model Pendidikan Entrepreneurship di Pondok Pesantren. Penelitian Sosial Keagamaan, 12(2), 395-416.

Fayolle, A. (2008). Entrepreneurship Education at a Crossroads: Towards a More Mature Teaching Field. Journal of Enterprising Culture, 16(04), 325337.

Grover, N. A. N. (2015). Measuring Retail Supply Chain Performance: Theoretical Model Using Key Performance Indicators (KPIs). Benchmarking: An International Journal, 22(1), 135-166.

Gunawan, A., \& Hazwardy, D. (2020). Pelatihan Digital Entrepreneurship untuk Mewujudkan Generasi Milenial Berjiwa Wirausaha. Abdimas Dewantara, 3(1), 81-88.

Hayati, H., Ismawirna, I., \& Yeniningsih, T. K. (2020). Pengembangan Karakter Mandiri melalui Kegiatan Entrepreneurship Berintegritas pada Fakultas Agama Islam di Universitas Serambi Mekkah Banda Aceh. Visipena, 11(1), 60-76.

Klasik, D., \& Hutt, E. L. (2019). Bobbing for Bad Apples: Accreditation, Quantitative Performance Measures, and The Identification of LowPerforming Colleges. The Journal of Higher Education, 90(3), 427-461.

Kompri. (2017). Standarisasi Kompetensi Kepala Sekolah. Jakarta: Kencana.

Margahana, H. (2020). Urgensi Pendidikan Entrepreneurship dalam Membentuk Karakter Entrepreneur Mahasiswa. Jurnal Ilmiah Ekonomi dan Bisnis, 17(2), 176-183.

Mulyasa, E. (2012). Manajemen dan Kepemimpinan Kepala Sekolah. Jakarta: Bumi Aksara.

Mundiri, A., \& Manshur, U. (2020). School Principals' Self-Identity According to The Perspective of Transpersonal Psychology. Al-Tahrir: Jurnal Pemikiran Islam, 20(1), 75-95. https:/ / doi.org/10.21154/altahrir.v20i1.2005

Nurjanah, S. (2019). Pendidikan Entrepreneurship Perguruan Tinggi Keagamaan Islam Swasta (Studi Kasus di STIT Makhdum Ibrahim Tuban). Al Hikmah: Jurnal Studi Keislaman, 9(1), 93-100. 
Paramita, S., \& Erdiansyah, R. (2016). Entrepreneurship dan New Media pada Generasi Muda. Kaji Tindak: Jurnal Pemberdayaan Masyarakat, 3(1), 1-8.

Rahman, A., \& Subiyantoro, S. (2021). The Leardership Role of School Principals in Online Learning During the Covid-19 Pandemic. Al-Tanzim: Jurnal Manajemen Pendidikan Islam, 5(1), 165-175. https://doi.org/10.33650/altanzim.v5i1.1805

Russamsi, Y., Hadian, H., \& Nurlaeli, A. (2020). Pengaruh Kepemimpinan Kepala Sekolah dan Peningkatan Profesional Guru terhadap Kinerja Guru di Masa Pandemi Covid-19. Managere: Indonesian Journal of Educational Management, 2(3), 244-255.

Syam, A., Akib, H., Yunus, M., \& Hasbiah, S. (2018). Determinants of Entrepreneurship Motivation for Students at Educational Institution and Education Personnel in Indonesia. Journal of Entrepreneurship Education, 21(2), 1-12.

Subiantoro, M. D. (2017). Manajemen Kurikulum Berbasis Entrepreneurship di SMA Muhammadiyah 9 Surabaya. JDMP (Jurnal Dinamika Manajemen Pendidikan), 1(1), 55-67.

Subroto, W. T. (2015). Menanamkan Nilai-nilai Entrepreneurship melalui Pendidikan Ekonomi pada Era Masyarakat Ekonomi Asean. Jurnal Economia, 11(1), 16-25.

Suryaman, S., \& Karyono, H. (2018). Pengintegrasian Nilai-nilai Kewirausahaan Berbasis Multikultural. Sosiohumanika, 11(1), 63-78.

Tyler, D. E. (2016). Communication Behaviors of Principals at High Performing Title I Elementary Schools in Virginia: School Leaders, Communication, and Transformative Efforts. Creighton Journal of Interdisciplinary Leadership, 2(2), 2-16.

Zulhimma, H. (2018). Upaya Kewirausahaan dalam Meningkatkan Kemandirian Ekonomi Lembaga Pendidikan Islam. Tazkir: Jurnal Penelitian Ilmu-ilmu Sosial dan Keislaman, 4(2), 313-328. 